\title{
Ethnobotanical Uses of Plants among the Bhotiya Tribal Communities of Niti Valley in Central Himalaya, India
}

\author{
P. C. Phondani, R. K. Maikhuri, L. S. Rawat, N. A. Farooquee, \\ C.P. Kala, S.C.R. Vishvakarma, K.S. Rao and K.G. Saxena
}

\section{Research}

\begin{abstract}
A study of the medicinal plants and knowledge of diseases was conducted in Bhotiya tribal communities in the Niti valley of Alaknanda catchment in Central Himalaya. Indigenous knowledge of local traditional healers about plants used for medicinal purposes was collected through questionnaire and interviews. Eighty-six plant species were identified as being used for treatment of 37 common ailments. The methods and application of uses of these plants varies and was based on the nature of disease.
\end{abstract}

\section{Introduction}

There are over 53 million tribal people in India belonging to 550 communities of 227 ethnic groups (Maikhuri \& Gangwar 1993, Nautiyal et al. 2000). These tribal communities draw their sustenance largely from forests for food, medicine and other requirements. Forests represent a whole way of life for tribal peoples and as such their life and economy are, therefore, intimately interwoven with the forests and forest wealth (Gangwar \& Ramakrishnan 1990). The mountainous region of the Himalaya is inhabited by diverse tribal communities, and among these the Bhotiyas mainly inhabit the high altitude areas of Uttarakhand state in India and practice transhumance pastoralism (Farooquee 1994, Kala 2005, Maikhuri et al. 1998).

The Bhotiya tribal communities have a wealth of knowledge on the use of medicinal plants in their locality. Collection of medicinal plants from the wild is has long been conducted while grazing livestock in the forests and alpine pastures. Several medicinal plants have been listed as endangered, vulnerable and threatened due to over exploitation or unskillful harvesting in the forest and alpine meadows (Farooquee \& Saxena 1996, Kala 1998, Kala 2002, Maikhuri et al. 1998, 2000, Nautiyal et al. 2000) and also due to commercial exploitation by a number of individuals and agencies.
Therefore, the present study is an attempt:

1. to identify the plants being used for medicinal purposes by the Bhotiya tribal communities in order to better characterize their pharmacopoeia.

2. to better understand Bhotiya knowledge about their health care system for treating different diseases in order to understand the basis for their interactions with the forests.

\section{Study Area and methods}

The River Alaknanda originates in the Satopanth and Bhagirath kharak glacier, which rise from the eastern slope of Chaukamba peak $(7138 \mathrm{~m}$.) of Rudraprayag district of Uttarakhand state. In its course of $141.5 \mathrm{~km}$ it drains approximately $11000 \mathrm{~km}^{2}$ area. The catchment area of Alaknanda river extends between $29^{\circ} 58^{\prime} 34^{\prime \prime}$ to

\section{Correspondence}

P.C. Phondani, R.K. Maikhuri, L.S. Rawat, N. A. Farooquee, G.B. Pant Institute of Himalayan Environment and Development, P. Box 92, Garhwal Unit, Srinagar Garhwal, Uttarakhand - 246 174, INDIA.

rkmaikhuri@rediffmail.com

C.P. Kala, Ecosystem \& Environment Management, Indian Institute of Forest Management, Nehru Nagar, Bhopal, Madhya Pradesh - 462 003, INDIA.

S.C.R. Vishvakarma, G.B. Pant Institute of Himalayan Environment and Development, Kosi - Katarmal, Almora, INDIA.

K.S. Rao, Department of Botany, University of Delhi, New Delhi - 110007, INDIA

K.G. Saxena, School of Environmental Sciences, Jawaharlal Nehru University, New Delhi, INDIA.

Ethnobotany Research \& Applications 8:233-244 (2010)

Published: August 05, 2010 
$31^{\circ} 04^{\prime} 20^{\prime \prime} \mathrm{N}$ and $78^{\circ} 34^{\prime} 31^{\prime \prime}$ to $80^{\circ} 17^{\prime} 54^{\prime \prime} \mathrm{E}$. It narrows down towards the west and tapers off at Devprayag to a confluence with the river Bhagirathi forming the holy Ganga. It covers a wide range of climatic conditions under an altitudinal variation of 642-7817 meter altitude above sea level (m.a.s.I.). The Alaknanda catchment area stretches into four districts of Garhwal region of Uttarakhand state in India viz., Chamoli, Rudraprayag, Pauri and Tehri.

The present study was carried out in 15 villages inhabited by Tolchha and Marcha sub-communities of the Bhotiya community in the Niti valley of Alaknanda catchment in Central Himalaya, Uttarakhand state of India (Figure 1).

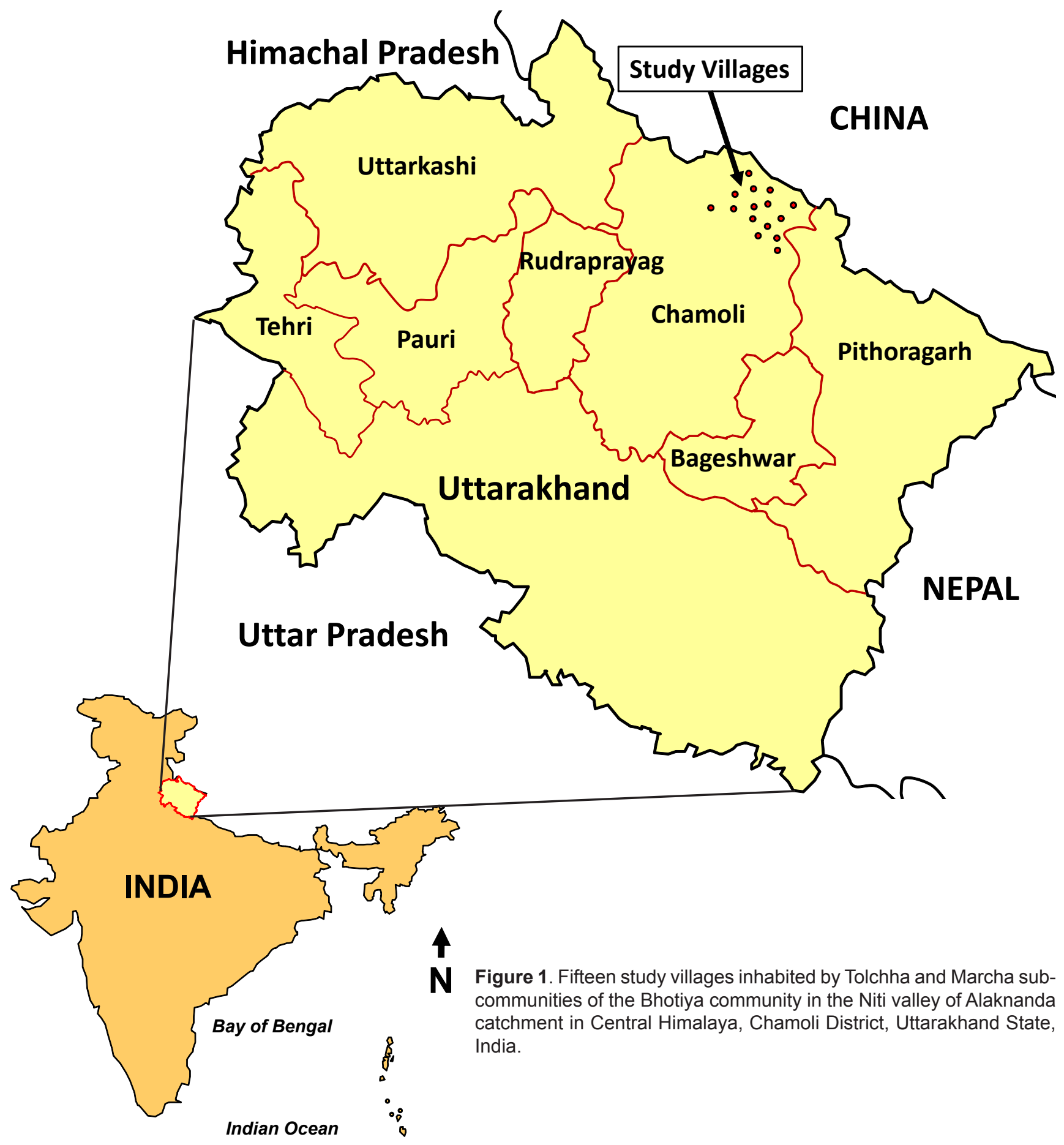




\section{Phondani et al. - Ethnobotanical Uses of Plants among the Bhotiya Tribal Communities of Niti Valley in Central Himalaya, India}

The 15 Bhotiya villages (Bampa, Dronagiri, Farki, Garpak, Ghamshali Jhuma, Kaga, Kaileshpur, Lata, Malari, Niti, Phagti, Reni, Suraithota, Tolma) mainly occupy the forested regions and have a total population of 6378 with an average family size of 5-6 persons. All primary rural settlements except for Lata, Phagti, Reni, Suraithota and Tolma are located below 2000 m.a.s.l. All households of Jhuma, Garpak, Kaga, Dronagiri, Malari, Kaileshpur, Farki, Bampa, Ghamshali and Niti villages, have two permanent dwellings; one in the high altitude between 2000 to 3500 m.a.s.l., and other in the low altitude between 800 to 1500 m.a.s.l. and all of them practice transhumance every year between summer and winter settlements. The Bhotiya have their own culture, tradition and religious beliefs. Their major occupations have been sheep rearing and agriculture, with agriculture taking precedence over pastoralism at present. Almost all of the households are involved in agricultural activities by way of subsistence farming.

Three basic approaches were adopted to study the uses of plants by Bhotiya communities in the region.

1. An interview based approach in which questions related to the uses of plants for different purposes (i.e., medicine, food, fuel, fodder etc.) was recorded with the help of an informant while making visits to the forests for identifications.

2. An inventory based approach involving collection of plant specimens and subsequent interviews with informants requesting names and uses of the plants collected.

3. An interactive discussions approach through workshops/meetings and discussions held with various stakeholders. Traditional herbal healers (vaidyas), scientists, medical doctors, forest officers, environmentalists, school teachers, social workers and local people were invited to hold discussions about the different uses of plants, methods and periods of collection, their conservation strategies and the fate of traditional knowledge systems, etc. Questionnaires were filled by participants to understand the utilization pattern of plant species used for treating different ailments.

Information related to composition of medicines prepared for treating different ailments for a particular period of time was obtained from traditional herbal healers of the studied community. Cross-checking of collected information was done during field visits.

The collected plant specimens were identified with the help of regional floras (Gaur 1999, Naithani 1985) and taxonomists. Specimens of each species identified were brought to the G.B. Pant Institute (Garhwal Unit) herbarium for scientific identification where they were subsequently deposited. This study was carried out between December 2006 to December 2008.

\section{Results}

Eighty-six plant species distributed in 43 families were documented (Table 1) that were used in treating 37 ailments (Table 2) in the high altitude areas occupied by the Bhotiya tribal communities. Twenty-five species were used for treating more than one disease. Fourteen species were mostly used in the treatment of skin diseases.

Table 1. Plants documented as used medicinally among the Bhotiya communities of Niti valley in Central Himalaya, India.

\begin{tabular}{|l|l|l|l|}
\hline Scientific name & Vernacular name & Source/Locality & Habit \\
\hline Achyranthes aspera L. (Amaranthaceae) & Latjiri, Apamarg & Road side & Herb \\
\hline Aconitum balfourii Stapf (Ranunculaceae) & Mithabish & Alpine forest & Herb \\
\hline Aconitum heterophyllum Wall. ex Royle (Ranunculaceae) & Atis & Sub-alpine forest & Herb \\
\hline Aesculus indica (Wall. ex Cambess.) Hook. (Sapindaceae) & Pangar & Montane forest & Tree \\
\hline Allium cepa L. (Amaryllidaceae) & Pyaz & Kitchen garden & Herb \\
\hline Allium humile Kunth (Amaryllidaceae) & Jambu Faran & Kitchen garden & Herb \\
\hline Allium sativum L. (Amaryllidaceae) & Lashun & Kitchen garden & Herb \\
\hline Angelica glauca Edgew. (Apiaceae) & Choru & Sub-alpine forest & Herb \\
\hline Arisaema tortuosum (Wall.) Schott (Araceae) & Bag-Mungri & $\begin{array}{l}\text { Road sides, } \\
\text { near forest }\end{array}$ & Herb \\
\hline Arnebia benthamii (Wall. ex G. Don) I.M. Johnst. (Boraginaceae) & Balchari & Sub-alpine forest & Herb \\
\hline Asparagus racemosus Willd. (Liliaceae) & Sataver, Jhirna & $\begin{array}{l}\text { Submontane to } \\
\text { montane forest }\end{array}$ & Shrub \\
\hline Berberis aristata DC. (Berberidaceae) & Chotru & Montane forest & Shrub \\
\hline Berberis lycium Royle (Berberidaceae) & Kirmor & Middle hill forest & Shrub \\
\hline Bergenia ciliata Sternb. (Saxifragaceae) & Silphori & Sub-alpine forest & Herb \\
\hline
\end{tabular}




\begin{tabular}{|c|c|c|c|}
\hline Scientific name & Vernacular name & Source/Locality & Habit \\
\hline Betula alnoides Buch.-Ham. ex D. Don (Betulaceae) & Saur & $\begin{array}{l}\text { Sub montane to } \\
\text { montane forest }\end{array}$ & Tree \\
\hline Betula utilis D. Don (Betulaceae) & Bhojpatra & Montane forest & Tree \\
\hline Brassica campestris L. (Brassicaceae) & Sarsoo & Crop field & Herb \\
\hline Brassica juncea (L.) Czern. (Brassicaceae) & Rai & Kitchen garden & Herb \\
\hline Cannabis sativa L. (Cannabaceae) & Bhang & Road sides & Herb \\
\hline Capsicum annuum L. (Solanaceae) & Mirch & Kitchen garden & Herb \\
\hline Carum carvi L. (Apiaceae) & Kalajeera & Kitchen garden & Herb \\
\hline Cedrus deodara (Roxb. ex D. Don) G. Don (Pinaceae) & Devdar & Montane forest & Tree \\
\hline Centella asiatica (L.) Urb. (Apiaceae) & Brahmi & Roadside & Herb \\
\hline Cicerbita macrorhiza (Royle) Beauverd (Asteraceae) & Karatu & Montane forest & Herb \\
\hline Cirsium verutum (D. Don) Spreng. (Asteraceae) & Biskanara & Montane forest & Herb \\
\hline Corydalis cornuta Royle (Fumariaceae) & Chitra jhar & Montane forest & Herb \\
\hline Cucumis sativus L. (Cucurbitaceae) & Kakree & Kichen garden & Herb \\
\hline Curcuma longa L. (Zingiberaceae) & Haldi & Kitchen garden & Herb \\
\hline Cuscuta reflexa Roxb. (Convolvulaceae) & Akash bel & Road side & Herb \\
\hline Cymbopogon martini (Roxb.) Will.Watson (Poaceae) & Mirchya ghass & Roadside & Herb \\
\hline Cynodon dactylon (L.) Pers. (Poaceae) & Dubla & Waste places & Herb \\
\hline Dactylorhiza hatagirea (D. Don) Soó (Orchidaceae) & Hatajari & Sub-alpine forest & Herb \\
\hline Datura stramonium L. (Solanaceae) & Dhatura & $\begin{array}{l}\text { Waste places, } \\
\text { Road sides }\end{array}$ & Herb \\
\hline $\begin{array}{l}\text { Delphinium denudatum Wall. ex Hook. f. \& Thomson } \\
\text { (Ranunculaceae) }\end{array}$ & Nirbishi & Middle hills forest & Herb \\
\hline Echinochloa frumentacea Link (Poaceae) & Jhangora & Crop field & Herb \\
\hline Excoecaria acerifolia Didr. (Euphorbiaceae) & Dudhlu & Montane forest & Herb \\
\hline Ficus semicordata Buch.-Ham. ex Sm. (Moraceae) & Khaina & Road side & Tree \\
\hline Galium aparine L. (Rubiaceae) & Lesskuri & Road side & Herb \\
\hline Glycine max (L.) Merr. (Fabaceae) & Kala bhatt & Crop field & Herb \\
\hline Hibiscus rosa-sinensis L. (Malvaceae) & Gudhal & Kitchen garden & Shrub \\
\hline Hippophae rhamnoides L. (Elaegnaceae) & Amesh & Montane forest & Shrub \\
\hline Hordeum vulgare L. (Poaceae) & Jau & Crop field & Herb \\
\hline Juglans regia L. (Juglandaceae) & Jangli akhrot & $\begin{array}{l}\text { Submontane to } \\
\text { montane forest }\end{array}$ & Tree \\
\hline Lyonia ovalifolia (Wall.) Drude (Ericaceae) & Anyar & Monate forest & Tree \\
\hline Macrotyloma uniflorum (Lam.) Verdc. (Fabaceae) & Gaheth & Crop Field & Herb \\
\hline Megacarpaea polyandra Benth. ex Madden (Brassicaceae) & Barmoa & Sub-alpine forest & Herb \\
\hline Mentha arvensis L. (Lamiaceae) & Podina & Kitchen garden & Herb \\
\hline Maianthemum purpureum (Wall.) La Frankie (Asparagaceae) & Puyanu & Sub-alpine forest & Herb \\
\hline Morina longifolia Wall. (Dipsacaceae) & Biskandru & Sub-alpine forest & Herb \\
\hline Nardostachys grandiflora DC. (Valerianceae) & Jatamansi & Sub-alpine forest & Herb \\
\hline Nepeta discolor Royle ex Benth. (Lamiaceae) & Khirku & Montane forest & Herb \\
\hline Paeonia emodi Wall. ex Royle (Paeoniaceae) & Chandra & Near forest & Herb \\
\hline Panicum miliaceum L. (Poaceae) & Cheena & Crop field & Herb \\
\hline Picrorhiza kurrooa Royle ex Benth. (Plantaginaceae) & Kutaki & Alpine forest & Herb \\
\hline
\end{tabular}




\section{Phondani et al. - Ethnobotanical Uses of Plants among the Bhotiya Tribal Communities of Niti Valley in Central Himalaya, India}

\begin{tabular}{|c|c|c|c|}
\hline Scientific name & Vernacular name & Source/Locality & Habit \\
\hline Pinus wallichiana A.B. Jacks. (Pinaceae) & Kail & Montane forest & Tree \\
\hline $\begin{array}{l}\text { Pleurospermum angelicoides (Wall. ex DC.) Benth. } \\
\text { ex C.B. Clarke (Apiaceae) }\end{array}$ & Chippi & Sub-alpine forest & Herb \\
\hline Podophyllum hexandrum Royle (Podophyllaceae) & Bankakri & Alpine forest & Herb \\
\hline Polygonatum verticillatum (L.) All. (Liliaceae) & Salam misri & Sub-alpine forest & Herb \\
\hline Potentilla lineata Trevir. (Rosaceae) & Bjradanti & Montane forest & Herb \\
\hline Quercus leucotrichophora A. Camus (Fagaceae) & Banj & $\begin{array}{l}\text { Sub-montane to } \\
\text { montane forest }\end{array}$ & Tree \\
\hline Raphanus sativus L. (Brassicaceae) & Muli & Kitchen garden & Herb \\
\hline Rheum australe D. Don (Polygonaceae) & Dolu & Alpine forest & Herb \\
\hline Rheum webbianum Royle (Polygonaceae) & Tatri & Montane forest & Herb \\
\hline Rhododendron anthopogon D. Don (Ericaceae) & Awon & Montane forest & Tree \\
\hline Rhododendron arboreum Sm. (Ericaceae) & Burans & Montane forest & Tree \\
\hline Sapindus saponaria L. (Sapindaceae) & Reetha & $\begin{array}{l}\text { Forest, Nearby } \\
\text { Village }\end{array}$ & Tree \\
\hline Saussurea costus (Falc.) Lipsch. (Asteraceae) & Kuth & Agriculture field & Herb \\
\hline Saussurea obvallata (DC.) Edgew. (Asteraceae) & Brahm kamal & Sub-alpine forest & Herb \\
\hline Swertia chirata (Wall.) C. B. Clarke (Gentianaceae) & Cheraita & Sub-alpine forest & Herb \\
\hline Taxus baccata L. (Taxaceae) & Thuner & Sub-alpine forest & Tree \\
\hline Terminalia arjuna (Roxb. ex DC.) Wight \& Arn. (Combretaceae) & Arjuna & Near forest & Tree \\
\hline Thalictrum javanicum Blume (Ranunculaceae) & Mamiri & Sub-alpine & Herb \\
\hline Urtica dioica L. (Urticaceae) & Kandali & Roadside & Shrub \\
\hline Vigna mungo (L.) Hepper (Fabaceae) & Kali dal & Crop field & Herb \\
\hline Zanthoxylum armatum DC. (Rutaceae) & Timru & Road side & Shrub \\
\hline Zingiber officinale Roscoe (Zingiberaceae) & Adrak & Kitchen garden & Herb \\
\hline
\end{tabular}

Table 2. Ailments treated with medicinal plants, preparation methods, and dosing from Bhotiya communities of the Niti valley in Central Himalaya, India. Standard dosing: (qd) once a day; (bid) twice a day; (tid) three times a day; (x1d) continuous for 1 day; (x3d) continuous for 3 days; (x7d) continuous for 7 days, (cm) continuous for 1 month; (pqa) continuous for 3 months; (psa) (x7d)(x7d) continuous 6 month; (pa) continuous for 1 year; (cst) continue same treatment for more than 1 year.

\begin{tabular}{|c|c|c|c|}
\hline Ailments & Plant used & Method of Preparation & Doses \\
\hline \multirow[t]{3}{*}{ Fever } & Cheraita (Swertia chirata) & $\begin{array}{l}\text { Fresh leaves and stems are milled and made into } \\
\text { a juice to drink with water. }\end{array}$ & $\begin{array}{l}1 \text { glassful } \\
\text { (bid) }(x 3 d)\end{array}$ \\
\hline & $\begin{array}{l}\text { Chippi (Pleurospermum } \\
\text { angelicoides) }\end{array}$ & $\begin{array}{l}50 \mathrm{gm} \text { root of chippi, } 10 \mathrm{gm} \text { of cumin (Cuminum } \\
\text { cyminum L.) seed and } 7-8 \text { grains of black pepper } \\
\text { (Piper nigrum L.) are milled together and boiled } \\
\text { with } 200 \mathrm{ml} \text { water on moderate flame for up to } \\
5-10 \text { minutes and kept for cooling. The liquid is } \\
\text { drunk to treat fever. }\end{array}$ & $\begin{array}{l}4 \text { spoonfuls } \\
\text { (tid) }(\times 3 d)\end{array}$ \\
\hline & Kutki (Picrorhiza kurrooa) & $\begin{array}{l}50 \mathrm{gm} \text { dried roots is milled along with } 2 \text { spoonfuls } \\
\text { of sugar and drunk with water. }\end{array}$ & $\begin{array}{l}1 \text { cupful (bid) } \\
(x 3 d)\end{array}$ \\
\hline \multirow[t]{2}{*}{ Headache } & $\begin{array}{l}\text { Atis (Aconitum } \\
\text { heterophyllum) }\end{array}$ & $\begin{array}{l}\text { Root paste applied on the forehead to treat } \\
\text { headache. }\end{array}$ & $5 \mathrm{gm}$ (bid) (x1d) \\
\hline & $\begin{array}{l}\text { Awon (Rhododendron } \\
\text { anthopogon) }\end{array}$ & $\begin{array}{l}100 \mathrm{gm} \text { powder of dried leaves is mixed with } 1 \\
\text { spoonful of sugar and } 200 \mathrm{ml} \text { water added and } \\
\text { boiled for a few minutes. After cooling, juice is } \\
\text { drunk to treat headache. }\end{array}$ & $20 \mathrm{ml}(\mathrm{bid})(\mathrm{x} 1 \mathrm{~d})$ \\
\hline
\end{tabular}




\begin{tabular}{|c|c|c|c|}
\hline Ailments & Plant used & Method of Preparation & Doses \\
\hline Headache & $\begin{array}{l}\text { Karatu (Cicerbita } \\
\text { macrorhiza) }\end{array}$ & $\begin{array}{l}\text { Juice of fresh leaves is drunk and root paste } \\
\text { rubbed on the forehead to treat headaches. }\end{array}$ & $\begin{array}{l}\text { 6-7 drops } \\
\text { (tid) }(\times 1 d)\end{array}$ \\
\hline \multirow[t]{3}{*}{$\begin{array}{l}\text { Cold and } \\
\text { cough }\end{array}$} & $\begin{array}{l}\text { Amesh (Hippophae } \\
\text { rhamnoides) }\end{array}$ & $\begin{array}{l}100 \mathrm{ml} \text { decoction of fruit juice is mixed with } 1 \\
\text { spoonful of sugar and } 30-40 \mathrm{gm} \text { of finger millet } \\
\text { (Eleusine coracana (L.) Gaertn.) and eaten to } \\
\text { treat cold and cough. }\end{array}$ & $20 \mathrm{gm}(\mathrm{bid})(\mathrm{x} 3 \mathrm{~d})$ \\
\hline & Bhojpatra (Betula utilis) & $\begin{array}{l}\text { 50gm resin of bhojpatra is boiled with } 250 \mathrm{ml} \\
\text { water on moderate flame for } 10-15 \text { minutes and } \\
\text { mixed with } 2 \text { spoonfuls of ghee and } 1 / 2 \text { spoonful of } \\
\text { salt and drunk to treat cold and cough. }\end{array}$ & $50 \mathrm{ml}(\mathrm{bid})(\mathrm{x} 3 \mathrm{~d})$ \\
\hline & Choru (Angelica glauca) & $\begin{array}{l}1 \mathrm{gm} \text { root powder is mixed with } 1 \mathrm{gm} \text { leaf powder } \\
\text { of basil (Ocimum basilicum L.) in } 1 \text { cup tea and } \\
\text { drunk to treat a common cold. }\end{array}$ & $\begin{array}{l}1 \text { cupful (tid) } \\
(\times 3 d)\end{array}$ \\
\hline \multirow[t]{5}{*}{$\begin{array}{l}\text { Wounds, } \\
\text { Cuts and } \\
\text { Boils }\end{array}$} & $\begin{array}{l}\text { Biskandru (Morina } \\
\text { longifolia) }\end{array}$ & $\begin{array}{l}\text { Juice of fresh leaves is mixed with } 3-4 \text { drops of } \\
\text { mustard oil and applied externally on the infected } \\
\text { portion to treat boils and wounds. }\end{array}$ & $20 \mathrm{ml}$ (bid) (x3d) \\
\hline & $\begin{array}{l}\text { Brahm kamal } \\
\text { (Saussurea obvallata) }\end{array}$ & $\begin{array}{l}100 \mathrm{ml} \text { decoction of dried leaves is mixed with } 1 / 2 \\
\text { spoonful of salt and a few drops of this is applied } \\
\text { in the infected portion to treat boils, cuts and } \\
\text { wounds. }\end{array}$ & $20 \mathrm{ml}$ (bid) (x3d) \\
\hline & Haldi (Curcuma longa) & Rhizome paste is applied to treat boils. & $5 g m($ bid) $(x 3 d)$ \\
\hline & $\begin{array}{l}\text { Hatajari (Dactylorhiza } \\
\text { hatagirea) }\end{array}$ & Root paste is applied to treat cuts. & $5 g m(b i d)(x 3 d)$ \\
\hline & Tatri (Rheum webbianum) & $\begin{array}{l}100 \mathrm{gm} \text { of dried leaf powder is mixed with Rumex } \\
\text { hastatus D. Don leaf powder and } 2 \text { spoonfuls of } \\
\text { mustard oil and applied externally to treat boils } \\
\text { and wounds. }\end{array}$ & $20 \mathrm{gm}(\mathrm{qd})(\times 3 d)$ \\
\hline \multirow[t]{2}{*}{ Diarrhea } & Podina (Mentha arvensis) & $\begin{array}{l}\text { Fresh leaves are milled with lashun to make a } \\
\text { chatni. This is eaten to treat diarrhea. }\end{array}$ & $5 g m($ tid $)(x 3 d)$ \\
\hline & Pyaz (Allium cepa) & $\begin{array}{l}1 \text { bulb milled and mixed with } 5 \mathrm{gm} \text { salt and drunk } \\
\text { with water. }\end{array}$ & $\begin{array}{l}1 / 2 \text { glassful } \\
\text { (bid) }(\times 3 d)\end{array}$ \\
\hline \multirow[t]{2}{*}{ Goiter } & Dolu (Rheum australe) & $\begin{array}{l}5 \mathrm{gm} \text { dry root milled with } 5 \mathrm{ml} \text { water and made into } \\
\text { a paste }\end{array}$ & $1 \mathrm{gm}(\mathrm{qd})(\mathrm{x} 7 \mathrm{~d})$ \\
\hline & Jambu faran (Allium humile) & $\begin{array}{l}5 \mathrm{gm} \text { dry leaves are fried in } 50 \mathrm{ml} \text { mustered oil and } \\
\text { rubbed in the infected part, and leaves used with } \\
\text { pulse. }\end{array}$ & $5 \mathrm{ml}(\mathrm{qd})(\mathrm{x} 7 \mathrm{~d})$ \\
\hline \multirow[t]{3}{*}{ Rheumatism } & Biskanara (Cirsium verutum) & $\begin{array}{l}100 \mathrm{gm} \text { root boiled with } 500 \mathrm{ml} \text { water is prepared } \\
\text { as a } 50 \mathrm{ml} \text { decoction which is further mixed with } \\
1-2 \text { spoonfuls of devdar oil and applied externally } \\
\text { on joints to treat rheumatism. }\end{array}$ & 4-5 drops (pqa) \\
\hline & $\begin{array}{l}\text { Dhatura (Datura } \\
\text { stramonium) }\end{array}$ & Seed paste is rubbed on to treat rheumatism. & $5 g m(b i d)(p q a)$ \\
\hline & $\begin{array}{l}\text { Jatamansi (Nardostachys } \\
\text { grandiflora) }\end{array}$ & $\begin{array}{l}10 \mathrm{gm} \text { root paste mixed with } 50 \mathrm{gm} \text { ghee (purified } \\
\text { semi-liquid butter), mildly heated for } 5 \text { minutes } \\
\text { and soon after, rubbed on the joints to treat } \\
\text { rheumatism. }\end{array}$ & $10 \mathrm{gm}$ (tid) (pqa) \\
\hline $\begin{array}{l}\text { High blood } \\
\text { pressure }\end{array}$ & Thuner (Taxus baccata) & $\begin{array}{l}1 \mathrm{gm} \text { dry powder of bark is mixed with } 1 \mathrm{gm} \text { salt, } \\
1 \text { spoonful ghee and } 1 \text { cupful of water to make a } \\
\text { namkeen tea. }\end{array}$ & $\begin{array}{l}\text { 1cupful } \\
\text { (bid) (cst) }\end{array}$ \\
\hline
\end{tabular}




\section{Phondani et al. - Ethnobotanical Uses of Plants among the Bhotiya Tribal Communities of Niti Valley in Central Himalaya, India}

\begin{tabular}{|c|c|c|c|}
\hline Ailments & Plant used & Method of Preparation & Doses \\
\hline \multirow[t]{3}{*}{ Asthma } & $\begin{array}{l}\text { Barmoa (Megacarpaea } \\
\text { polyandra) }\end{array}$ & $\begin{array}{l}100 \mathrm{ml} \text { root decoction of barmoa is mixed with } \\
1 \text { spoonful sugar and } 4-5 \text { drops of apricot }(P . \\
\text { armeniaca) oil and drunk to treat asthma. }\end{array}$ & $20 \mathrm{ml}$ (tid) (cst) \\
\hline & Bhojpatra (Betula utilis) & $\begin{array}{l}50 \mathrm{gm} \text { resin of bhojpatra is milled with } 20 \mathrm{gm} \\
\text { leaf powder of chandra and fried in } 2 \text { spoonfuls } \\
\text { apricot (Prunus armeniaca L.) oil and drunk to } \\
\text { treat asthma. }\end{array}$ & $25 \mathrm{ml}$ (tid) (cst) \\
\hline & Pharan (Allium humile) & $\begin{array}{l}5 \mathrm{gm} \text { dried leaves of pharan and } 10 \mathrm{gm} \text { root } \\
\text { powder of kuth are fried in } 2 \text { spoonfuls of ghee } \\
\text { and eaten to treat asthma. }\end{array}$ & $10 \mathrm{gm}(\mathrm{tid})(\mathrm{cst})$ \\
\hline \multirow[t]{3}{*}{ Paralysis } & Adrak (Zingiber officinale) & $\begin{array}{l}10 \mathrm{gm} \text { ginger rhizome is mixed with } 10 \mathrm{ml} \text { honey } \\
\text { and eaten. }\end{array}$ & $5 g m$ (bid) (cst) \\
\hline & Lashun (Allium sativum) & $\begin{array}{l}\text { 5-bulbs are fried in } 50 \mathrm{ml} \text { mustard oil and filtered. } \\
\text { The oil is then rubbed on the infected part before } \\
\text { sleeping. }\end{array}$ & $10 \mathrm{ml}(\mathrm{qd})(\mathrm{cst})$ \\
\hline & Silphori (Bergenia ciliata) & $\begin{array}{l}\text { Leaves are boiled in water, dried in sun light, and } \\
\text { made into a tea powder. The tea is used without } \\
\text { sugar and milk and drunk with goor ( } 4 \mathrm{gm} \text { goor } \\
\text { with half cup tea). }\end{array}$ & $1 / 2$ cup (bid) (psa) \\
\hline \multirow[t]{2}{*}{ Leprosy } & $\begin{array}{l}\text { Chitra jhar (Corydalis } \\
\text { cornuta) }\end{array}$ & Root paste is applied. & $1 g m(q d)(p q a)$ \\
\hline & $\begin{array}{l}\text { Mithabish (Aconitum } \\
\text { balfourii) }\end{array}$ & Root paste is applied. & $1 \mathrm{gm}(\mathrm{qd})(\mathrm{pqa})$ \\
\hline \multirow[t]{3}{*}{ Rabies } & Kandali (Urtica dioica) & $\begin{array}{l}5 \text { fresh leaves milled and mixed with } 1 \mathrm{gm} \text { chili } \\
\text { powder and made into a paste without water. }\end{array}$ & $1 \mathrm{gm}(\mathrm{qd})(\mathrm{x} 7 \mathrm{~d})$ \\
\hline & Mirch (Capsicum annuum) & 2 fruit milled and made into a powder. & $2 g m(q d)(x 7 d)$ \\
\hline & $\begin{array}{l}\text { Mirchya ghass } \\
\text { (Cymbopogon martini) }\end{array}$ & Fresh leaves are milled and made into a paste. & $1 g m(q d)(x 7 d)$ \\
\hline \multirow{6}{*}{$\begin{array}{l}\text { Snake bite/ } \\
\text { Scorpion } \\
\text { sting }\end{array}$} & $\begin{array}{l}\text { Banj (Quercus } \\
\text { leucotrichophora) }\end{array}$ & Seed paste is prepared and applied. & $1 \mathrm{gm}(\mathrm{bid})(\mathrm{x} 3 \mathrm{~d})$ \\
\hline & Kuth (Saussurea costus) & Root paste is applied. & $1 \mathrm{gm}(\mathrm{bid})(\mathrm{x} 3 \mathrm{~d})$ \\
\hline & Mirch (Capsicum annuum) & Fruit milled and made into a powder to apply. & $1 \mathrm{gm}(\mathrm{qd})(\times 3 d)$ \\
\hline & $\begin{array}{l}\text { Nirbishi (Delphinium } \\
\text { denudatum) }\end{array}$ & Root paste is applied. & $1 \mathrm{gm}$ (bid) (x3d) \\
\hline & Pyaz (Allium cepa) & $\begin{array}{l}30 \mathrm{ml} \text { juice of onion bulb is mixed with } 30 \mathrm{ml} \\
\text { mustard oil and made into a paste. }\end{array}$ & $1 \mathrm{gm}(\mathrm{bid})(\mathrm{x} 3 \mathrm{~d})$ \\
\hline & $\begin{array}{l}\text { Reetha (Sapindus } \\
\text { saponaria) }\end{array}$ & Seed mass milled and drunk with water. & $\begin{array}{l}1 \text { spoonful } \\
\text { (bid) }(\times 3 d)\end{array}$ \\
\hline \multirow[t]{3}{*}{ Bone fracture } & Arjuna (Terminalia arjuna) & $\begin{array}{l}\text { Bark is milled and made into a paste that is used } \\
\text { to plaster on fractured part then covered with bark } \\
\text { for } 28-35 \text { days. }\end{array}$ & $100 \mathrm{gm}(\mathrm{qd})(\mathrm{cm})$ \\
\hline & Kail (Pinus wallichiana) & $\begin{array}{l}\text { Resin is mildly heated and used to plaster on } \\
\text { fracture part, which is immediately covered by } \\
B \text {. utilis bark, which reduces the pain and treats } \\
\text { sprain and fracture. }\end{array}$ & $20 \mathrm{ml}(\mathrm{qd})(\mathrm{cm})$ \\
\hline & Kali dal (Vigna mungo) & $\begin{array}{l}250 \mathrm{gm} \text { seeds are mixed with } 250 \mathrm{ml} \text { water and } \\
\text { made into a paste that is used to plaster the } \\
\text { fractured part. This is then covered with bhojpatra/ } \\
\text { timru bark for } 28-35 \text { days. }\end{array}$ & $100 \mathrm{gm}(\mathrm{qd})(\mathrm{cm})$ \\
\hline
\end{tabular}




\begin{tabular}{|c|c|c|c|}
\hline Ailments & Plant used & Method of Preparation & Doses \\
\hline Bone fracture & Thuner (Taxus baccata) & $\begin{array}{l}\text { Yolk of fresh egg is mixed with thuner bark and } \\
\text { made into a paste that is used to plaster on } \\
\text { fractured part then covered with bark for } 28-35 \\
\text { days. }\end{array}$ & $100 \mathrm{gm}(\mathrm{qd})(\mathrm{cm})$ \\
\hline \multirow[t]{3}{*}{ Kidney stone } & $\begin{array}{l}\text { Gaheth (Macrotyloma } \\
\text { uniflorum) }\end{array}$ & $\begin{array}{l}250 \mathrm{gm} \text { of seeds are boiled with } 1 \text { liter of water and } \\
\text { seeds used in pulse continuously for } 7 \text { days. }\end{array}$ & $200 \mathrm{ml}$ (bid) (cst) \\
\hline & Kala bhatt (Glycine max) & $\begin{array}{l}\text { Seeds boiled in water to make a hot liquid soup } \\
\text { that is drunk to treat kidney stones. }\end{array}$ & $\begin{array}{l}1 \text { bowlful (qd) } \\
\text { (cst) }\end{array}$ \\
\hline & Silphori (Bergenia ciliata) & $\begin{array}{l}1 \mathrm{gm} \text { of root powder is used with } 1 \text { glass of water. } \\
\text { Dry leaf powder is used in tea. }\end{array}$ & $\begin{array}{l}1 / 2 \text { glassful }(q d) \\
\text { morning (cst) }\end{array}$ \\
\hline \multirow[t]{4}{*}{ Jaundice } & $\begin{array}{l}\text { Jhangora (Echinochloa } \\
\text { frumentacea) }\end{array}$ & Make a chaval (bhat) and consume it. & $\begin{array}{l}4-5 \text { spoonfuls } \\
\text { (bid) }(x 7 d)\end{array}$ \\
\hline & Kuth (Saussurea costus) & $\begin{array}{l}100 \mathrm{ml} \text { of root decoction of kuth is mixed with } 2 \\
\text { spoonfuls of honey and } 50 \mathrm{ml} \text { milk and drunk to } \\
\text { treat jaundice. }\end{array}$ & $50 \mathrm{ml}($ tid $)(x 7 \mathrm{~d})$ \\
\hline & Kutki (Picrorhiza kurrooa) & $\begin{array}{l}50 \mathrm{gm} \text { dried root and } 3 \text { spoonfuls sugar are dipped } \\
\text { in } 200 \mathrm{ml} \text { of water and left for one night. The next } \\
\text { day it is drunk to treat jaundice. }\end{array}$ & $50 \mathrm{ml}(\mathrm{tid})(\mathrm{x} 7 \mathrm{~d})$ \\
\hline & Muli (Raphanus sativus) & Used as a salad. & 1 root $(\mathrm{tid})(\mathrm{cm})$ \\
\hline \multirow[t]{3}{*}{ Cancer } & $\begin{array}{l}\text { Amesh (Hippophae } \\
\text { rhamnoides) }\end{array}$ & $\begin{array}{l}\text { Make a juice of mature fruit with } 250 \mathrm{gm} \text { of sugar } \\
\text { used in } 1 \text { liter juice. }\end{array}$ & $\begin{array}{l}2 \text { spoonfuls } \\
\text { (qd) before } \\
\text { sleeping (pqa) }\end{array}$ \\
\hline & $\begin{array}{l}\text { Bankakri (Podophyllum } \\
\text { hexandrum) }\end{array}$ & Root is prepared as a paste to be applied. & $1 \mathrm{gm}(\mathrm{qd})(\mathrm{psa})$ \\
\hline & Thuner (Taxus baccata) & $\begin{array}{l}1 \mathrm{gm} \text { dry of bark powder is mixed with } 1 \mathrm{gm} \text { of salt } \\
\text { and } 1 \text { spoonful of ghee for } 1 \text { cup water and makes } \\
\text { a namkeen tea. }\end{array}$ & 1cup (bid) (pa) \\
\hline \multirow[t]{4}{*}{ Diabetes } & Cheraita (Swertia chirata) & $\begin{array}{l}5 \mathrm{gm} \text { of leaves and stem are milled, steeped in } \\
250 \mathrm{ml} \text { of water over night, then filter and drunk. }\end{array}$ & $\begin{array}{l}1 \text { glass (qd) } \\
\text { morning (psa) }\end{array}$ \\
\hline & Kirmor (Berberis lycium) & $\begin{array}{l}5 \mathrm{gm} \text { of root is milled, steeped in } 250 \mathrm{ml} \text { of water } \\
\text { over night, then filter and drunk. }\end{array}$ & $\begin{array}{l}1 \text { glassfuls }(q d) \\
\text { Morning (psa) }\end{array}$ \\
\hline & Kutaki (Picrorhiza kurrooa) & $\begin{array}{l}5 \mathrm{gm} \text { of root is milled, steeped in a copper pot with } \\
250 \mathrm{ml} \text { of water over night, then filter and drunk. }\end{array}$ & $\begin{array}{l}1 \text { glassfuls }(q d) \\
\text { morning (psa) }\end{array}$ \\
\hline & $\begin{array}{l}\text { Mamiri (Thalictrum } \\
\text { javanicum) }\end{array}$ & $\begin{array}{l}5 \mathrm{gm} \text { of root is boiled with } 250 \mathrm{ml} \text { of water and } \\
\text { made into a decoction. }\end{array}$ & $\begin{array}{l}1 \text { spoonfuls }(q d) \\
\text { (cst) }\end{array}$ \\
\hline \multirow[t]{3}{*}{ Baldness } & Anyar (Lyonia ovalifolia) & $\begin{array}{l}10 \mathrm{gm} \text { of buds are milled with } 5 \mathrm{gm} \text { of jangli akhrot } \\
\text { bark, mixed with } 10 \mathrm{ml} \text { mustard oil, and made into } \\
\text { a paste. }\end{array}$ & $10 \mathrm{gm}(\mathrm{qd})(\mathrm{cm})$ \\
\hline & Balchari (Arnebia benthamii) & $\begin{array}{l}5 \mathrm{gm} \text { of root is milled, mixed with } 50 \mathrm{ml} \text { mustard oil, } \\
\text { and rubbed in hair. }\end{array}$ & $2 \mathrm{ml}(\mathrm{qd})(\mathrm{cst})$ \\
\hline & Khaina (Ficus semicordata) & Milky latex is collected to apply. & 1 drop $(\mathrm{qd})(\mathrm{cm})$ \\
\hline \multirow[t]{3}{*}{ Toothache } & Bjradanti (Potentilla lineata) & $\begin{array}{l}\text { A paste is prepared from the roots and used as an } \\
\text { ointment around the infected teeth. }\end{array}$ & $5 g m(q d)(x 7 d)$ \\
\hline & $\begin{array}{l}\text { Dhatura (Datura } \\
\text { stramonium) }\end{array}$ & $\begin{array}{l}\text { A paste is prepared from the seeds that may be } \\
\text { applied. }\end{array}$ & $5 g m(q d)(x 7 d)$ \\
\hline & Kuth (Saussurea costus) & $\begin{array}{l}100 \mathrm{ml} \text { of kuth tuber decoction is mixed with } 4-5 \\
\text { drops of apricot oil ( } P \text {. armeniaca) and } 1 / 2 \text { spoonful } \\
\text { of salt. A few small drops of this product are placed } \\
\text { on infected teeth to treat toothache. }\end{array}$ & $\begin{array}{l}1 \text { spoonfuls } \\
\text { (bid) }(x 3 d)\end{array}$ \\
\hline
\end{tabular}




\section{Phondani et al. - Ethnobotanical Uses of Plants among the Bhotiya Tribal Communities of Niti Valley in Central Himalaya, India}

\begin{tabular}{|c|c|c|c|}
\hline Ailments & Plant used & Method of Preparation & Doses \\
\hline Toothache & $\begin{array}{l}\text { Timru (Zanthoxylum } \\
\text { armatum) }\end{array}$ & A paste is prepared from the bark to be applied. & $5 \mathrm{gm}$ (bid) (cst) \\
\hline \multirow[t]{2}{*}{ Eye disease } & Chotru (Berberis aristata) & $\begin{array}{l}100 \mathrm{ml} \text { root decoction is made from } 100 \mathrm{gm} \text { of } \\
\text { roots with } 250 \mathrm{ml} \text { of water. Applied to treat eye } \\
\text { infection. }\end{array}$ & $\begin{array}{l}\text { 2-3 drops (tid) } \\
(x 7 d)\end{array}$ \\
\hline & Saur (Betula alnoides) & $\begin{array}{l}100 \mathrm{gm} \text { of bark ash is mixed with } 2 \text { spoonfuls of } \\
\text { ghee to form a paste that is applied on the eye lid } \\
\text { to treat eye disease/eye infection. }\end{array}$ & $5 g m(t i d)(x 7 d)$ \\
\hline \multirow[t]{3}{*}{ Ear disease } & Akash bel (Cuscuta reflexa) & $\begin{array}{l}\text { The whole plant is ground, filtered, and drops of } \\
\text { the resulting liquid applied. }\end{array}$ & $\begin{array}{l}1 \text { drop }(q d) \\
\text { before sleeping } \\
(x 7 d)\end{array}$ \\
\hline & Jau (Hordeum vulgare) & $\begin{array}{l}\text { Fresh leaves are milled then filtered with the } \\
\text { resulting drops being applied. }\end{array}$ & $\begin{array}{l}1 \text { drop }(q d) \\
\text { before sleeping } \\
(x 7 d)\end{array}$ \\
\hline & $\begin{array}{l}\text { Mirchya ghass } \\
\text { (Cymbopogon martini) }\end{array}$ & $\begin{array}{l}\text { Fresh leaves are milled and filtered with the } \\
\text { resulting drops being applied }\end{array}$ & $\begin{array}{l}1 \text { drop (qd) } \\
\text { before sleeping }\end{array}$ \\
\hline \multirow[t]{5}{*}{ Dyspepsia } & $\begin{array}{l}\text { Atis (Aconitum } \\
\text { heterophyllum) }\end{array}$ & $\begin{array}{l}50 \mathrm{gm} \text { of tuber is boiled with } 400 \mathrm{ml} \text { of water } \\
\text { to prepare a decoction of } 100 \mathrm{ml} \text { after which } 2 \\
\text { spoonfuls of sugar are added. }\end{array}$ & $20 \mathrm{ml}(\mathrm{bid})(\mathrm{x} 3 \mathrm{~d})$ \\
\hline & Chandra (Paeonia emodi) & $\begin{array}{l}50 \mathrm{gm} \text { of dried chandra leaves are milled } \\
\text { with } 10 \mathrm{gm} \text { dried barmoa root. }\end{array}$ & $20 \mathrm{gm}(\mathrm{tid})(\times 3 \mathrm{~d})$ \\
\hline & $\begin{array}{l}\text { Chippi (Pleurospermum } \\
\text { angelicoides) }\end{array}$ & $\begin{array}{l}50 \mathrm{gm} \text { of root paste of chippi is mixed with } 20 \mathrm{gm} \\
\text { of dried leaves of Allium spp. and fried with } 3 \\
\text { spoonfuls of ghee. }\end{array}$ & $20 \mathrm{gm}(\mathrm{bid})(\mathrm{x} 3 \mathrm{~d})$ \\
\hline & Kutki (Picrorhiza kurrooa) & $\begin{array}{l}50 \mathrm{gm} \text { of dried root is milled with } 2 \text { spoonfuls of } \\
\text { sugar and } 5 \mathrm{gm} \text { of dried Acorus calamus L. roots. }\end{array}$ & $20 \mathrm{gm}$ (bid) (x3d) \\
\hline & $\begin{array}{l}\text { Puyanu (Maianthemum } \\
\text { purpureum) }\end{array}$ & $\begin{array}{l}50 \mathrm{gm} \text { dried leaves is fried in } 4-5 \text { spoonfuls of } P \text {. } \\
\text { persica oil. }\end{array}$ & $20 \mathrm{gm}(\mathrm{tid})(\times 3 \mathrm{~d})$ \\
\hline \multirow[t]{4}{*}{$\begin{array}{l}\text { Stomach- } \\
\text { ache }\end{array}$} & $\begin{array}{l}\text { Atis (Aconitum } \\
\text { heterophyllum) }\end{array}$ & $5 \mathrm{gm}$ of root powder is mixed with 1 cup of water. & $\begin{array}{l}1 \text { cupful (bid) } \\
(\times 3 d)\end{array}$ \\
\hline & $\begin{array}{l}\text { Barmoa (Megacarpaea } \\
\text { polyandra) }\end{array}$ & $\begin{array}{l}100 \mathrm{gm} \text { of dried barmoa leaves are mixed with } \\
10 \mathrm{gm} \text { of thuner bark powder and fried in } 2-3 \\
\text { spoonfuls of ghee. }\end{array}$ & $20 \mathrm{gm}(\mathrm{tid})(\mathrm{x} 3 \mathrm{~d})$ \\
\hline & Kalajeera (Carum carvi) & $\begin{array}{l}20 \mathrm{gm} \text { of kalajeera seeds are mixed with } 5 \mathrm{gm} \\
\text { of Plantago ovata Forssk. and milled with } 5 \mathrm{gm} \\
\text { Sindhi salt and } 10 \mathrm{gm} \text { of kuth root. }\end{array}$ & $10 \mathrm{gm}(\mathrm{bid})(\mathrm{x} 3 \mathrm{~d})$ \\
\hline & Kutki (Picrorhiza kurrooa) & $\begin{array}{l}50 \mathrm{gm} \text { of root is dipped in } 200 \mathrm{ml} \text { water for } 2-3 \text { hours } \\
\text { and afterwards } 2 \text { spoonfuls of honey is added in. }\end{array}$ & $\begin{array}{l}3 \text { spoonfuls }(q d) \\
(x 3 d)\end{array}$ \\
\hline \multirow[t]{3}{*}{$\begin{array}{l}\text { Stomach } \\
\text { worm }\end{array}$} & Brahmi (Centella asiatica) & $\begin{array}{l}\text { The whole plant is ground into a powder. } 5 \mathrm{gm} \text { of } \\
\text { powder is used in } 1 \text { cup of water. }\end{array}$ & $\begin{array}{l}1 \text { cupful (qd) } \\
\text { morning (pqa) }\end{array}$ \\
\hline & Devdar (Cedrus deodara) & Oil is prepared for application. & $\begin{array}{l}1 / 2 \text { spoonful } \\
(\mathrm{qd})(\mathrm{cm})\end{array}$ \\
\hline & $\begin{array}{l}\text { Dudhlu (Excoecaria } \\
\text { acerifolia) }\end{array}$ & $\begin{array}{l}\text { Paste is prepared from roots for external } \\
\text { application. }\end{array}$ & $2 \mathrm{gm}(\mathrm{qd})(\mathrm{cm})$ \\
\hline \multirow[t]{2}{*}{ Dysentery } & Chandra (Paeonia emodi) & Leaves are milled and made into a juice. & $\begin{array}{l}1 \text { spoonful (tid) } \\
(x 7 d)\end{array}$ \\
\hline & Dubla (Cynodon dactylon) & $\begin{array}{l}100 \mathrm{gm} \text { of root powder is mixed with } 5 \mathrm{gm} \text { of } \\
\text { Valeriana jatamansi Jones powder and } 5 \mathrm{gm} \text { of } \\
\text { sugar which is drunk with } 1 \text { glass of water. }\end{array}$ & $\begin{array}{l}1 \text { glassful (bid) } \\
(x 7 d)\end{array}$ \\
\hline
\end{tabular}




\begin{tabular}{|c|c|c|c|}
\hline Ailments & Plant used & Method of Preparation & Doses \\
\hline \multirow[t]{2}{*}{ Anemia } & Rai (Brassica juncea) & Vegetable is applied. & 1 bowl (qd) (cst) \\
\hline & Kandali (Urtica dioica) & Vegetable is applied. & 1 bowl (qd) (cst) \\
\hline Abortion & $\begin{array}{l}\text { Gudhal (Hibiscus } \\
\text { rosa-sinensis) }\end{array}$ & One mature flower is fried with $10 \mathrm{ml}$ of ghee. & $5 g m(b i d)(x 7 d)$ \\
\hline \multirow[t]{2}{*}{ Leucorrhoea } & Brahmi (Centella asiatica) & $\begin{array}{l}10 \mathrm{gm} \text { of fresh brahmi leaves are mixed with } 5 \mathrm{gm} \\
\text { of kuth root powder and } 5 \mathrm{gm} \text { of atis root powder } \\
\text { and made into a juice to drink with water. }\end{array}$ & $\begin{array}{l}3 \text { spoonfuls (bid) } \\
(\times 3 d)\end{array}$ \\
\hline & $\begin{array}{l}\text { Salam misri (Polygonatum } \\
\text { verticillatum) }\end{array}$ & $\begin{array}{l}1 \mathrm{gm} \text { of root powder is mixed with one glassful of } \\
\text { water. }\end{array}$ & $\begin{array}{l}1 \text { glassful (bid) } \\
(\times 3 d)\end{array}$ \\
\hline \multirow[t]{2}{*}{ Pregnancy } & Bhojpatra (Betula utilis) & $\begin{array}{l}100 \mathrm{gm} \text { of bhojpatra resin and } 50 \mathrm{gm} \text { of kirol } \\
\text { (Prunus persica (L.) Batsch) seed kernels are } \\
\text { ground into a paste and then mixed with } 2 \\
\text { spoonfuls of honey. This is eaten by women } \\
\text { during their period of pregnancy to provide internal } \\
\text { strength and also to control miscarriage. }\end{array}$ & $100 \mathrm{gm}$ (tid) (psa) \\
\hline & $\begin{array}{l}\text { Jangli akhrot } \\
\text { (Juglans regia) }\end{array}$ & $\begin{array}{l}\text { Oil extracted from the seed kernels is mildly } \\
\text { heated and rubbed on swollen legs of pregnant } \\
\text { women. }\end{array}$ & $20 \mathrm{ml}$ (tid) (psa) \\
\hline $\begin{array}{l}\text { Urinary } \\
\text { disorder }\end{array}$ & Kakree (Cucumis sativus) & Seeds are ground and mixed with water. & $\begin{array}{l}1 \text { glassful (bid) } \\
(x 7 d)\end{array}$ \\
\hline \multirow[t]{2}{*}{ Tuberculosis } & $\begin{array}{l}\text { Biskandru (Cirsium } \\
\text { verutum) }\end{array}$ & $\begin{array}{l}100 \mathrm{gm} \text { of dried biskandru root is milled with } \\
20 \mathrm{gm} \text { of kuth root and } 20 \mathrm{gm} \text { of dried chandra } \\
\text { leaves. This mixture is dipped into } 500 \mathrm{ml} \text { of water } \\
\text { for } 2-3 \text { hour and then eaten. }\end{array}$ & $50 \mathrm{ml}$ (tid) (cst) \\
\hline & Khirku (Nepeta discolor) & $\begin{array}{l}150 \mathrm{ml} \text { decoction of dried leaves is mixed with } 2-3 \\
\text { spoonfuls of honey. }\end{array}$ & 100ml (tid) (cst) \\
\hline \multirow[t]{2}{*}{$\begin{array}{l}\text { Cardiac } \\
\text { disorders }\end{array}$} & $\begin{array}{l}\text { Brahm kamal } \\
\text { (Saussurea obvallata) }\end{array}$ & $\begin{array}{l}\text { A } 200 \mathrm{ml} \text { decoction of roots or leaves is mixed with } \\
2-3 \text { spoonfuls of devdar oil and applied externally } \\
\text { to treat the heart. }\end{array}$ & $100 \mathrm{ml}(\mathrm{qd})(\mathrm{psa})$ \\
\hline & $\begin{array}{l}\text { Burans (Rhododendron } \\
\text { arboreum) }\end{array}$ & Flower juice is prepared and applied. & $\begin{array}{l}1 \text { cupful (bid) } \\
\text { (psa) }\end{array}$ \\
\hline \multirow[t]{4}{*}{ Piles } & Bag (Arisaema tortuosum) & Fruit paste is prepared for application. & $1 \mathrm{gm}(\mathrm{qd})(\mathrm{x} 7 \mathrm{~d})$ \\
\hline & Bhang (Cannabis sativa) & Leaf paste is prepared for application. & $1 \mathrm{gm}(\mathrm{qd})(\mathrm{x} 7 \mathrm{~d})$ \\
\hline & Kinmor (Berberis lycium) & $\begin{array}{l}50 \mathrm{gm} \text { of root powder is mixed with } 50 \mathrm{ml} \text { of water } \\
\text { for preparation of a tablet. }\end{array}$ & $\begin{array}{l}1 \text { tablet (bid) } \\
(\mathrm{x} 7 \mathrm{~d})\end{array}$ \\
\hline & Silphori (Bergenia ciliata) & Root is chewed. & $1 \mathrm{gm}(\mathrm{bid})(\mathrm{x} 7 \mathrm{~d})$ \\
\hline \multirow[t]{3}{*}{ Epilepsy } & Adrak (Zingiber officinale) & Rhizomes are milled and mixed with cow ghee. & $5 \mathrm{gm}(\mathrm{qd})(\mathrm{cst})$ \\
\hline & Brahmi (Centella asiatica) & Leaf powder is mixed with cow ghee. & $5 \mathrm{gm}(\mathrm{qd})(\mathrm{psa})$ \\
\hline & $\begin{array}{l}\text { Sataver, Jhirna } \\
\text { (Asparagus racemosus) }\end{array}$ & Root powder is mixed with cow ghee. & $2 g m(q d)(p s a)$ \\
\hline \multirow[t]{2}{*}{$\begin{array}{l}\text { Mental } \\
\text { disorder }\end{array}$} & $\begin{array}{l}\text { Brahm kamal } \\
\text { (Saussurea obvallata) }\end{array}$ & $\begin{array}{l}\text { Seeds are milled into a powder. The powder is } \\
\text { steeped in water overnight then filtered. }\end{array}$ & $\begin{array}{l}1 \text { cupful (qd) } \\
\text { (psa) }\end{array}$ \\
\hline & Brahmi (Centella asiatica) & Leaf paste is prepared for application. & $5 \mathrm{gm}(\mathrm{qd})(\mathrm{psa})$ \\
\hline \multicolumn{4}{|l|}{ Skin diseases } \\
\hline \multirow[t]{2}{*}{ Measles } & $\begin{array}{l}\text { Cheena (Panicum } \\
\text { miliaceum) }\end{array}$ & Make a chaval (bhat) for consumption. & $\begin{array}{l}100 \mathrm{gm}(\mathrm{qd}) \\
(\mathrm{x} 7 \mathrm{~d})\end{array}$ \\
\hline & $\begin{array}{l}\text { Sarsoo (Brassica } \\
\text { campestris) }\end{array}$ & Oil is prepared for application. & $5 \mathrm{ml}(\mathrm{qd})(\mathrm{x} 7 \mathrm{~d})$ \\
\hline
\end{tabular}




\section{Phondani et al. - Ethnobotanical Uses of Plants among the Bhotiya Tribal Communities of Niti Valley in Central Himalaya, India}

\begin{tabular}{|c|c|c|c|}
\hline Ailments & Plant used & Method of Preparation & Doses \\
\hline \multirow[t]{4}{*}{ Itching } & $\begin{array}{l}\text { Akash matri } \\
\text { (Cuscuta reflexa) }\end{array}$ & $\begin{array}{l}\text { The whole plant is ground and mixed with Rumex } \\
\text { dentatus L. leaf powder and mustard oil to make } \\
\text { a paste. }\end{array}$ & $5 g m(q d)(x 3 d)$ \\
\hline & Anyar (Lyonia ovalifolia) & $\begin{array}{l}5 \mathrm{gm} \text { of new plant buds are ground and mixed with } \\
5 \mathrm{ml} \text { of mustard oil. This is rubbed in the affected } \\
\text { part. }\end{array}$ & $\begin{array}{l}5 \mathrm{ml}(\mathrm{qd}) \text { before } \\
\text { sleeping }(x 7 \mathrm{~d})\end{array}$ \\
\hline & Devdar (Cedrus deodara) & Bark oil is prepared for application. & $5 \mathrm{ml}(\mathrm{qd})(\mathrm{x} 3 \mathrm{~d})$ \\
\hline & Kuth (Saussurea costus) & Root paste is prepared for application. & $5 g m(q d)(x 3 d)$ \\
\hline \multirow[t]{3}{*}{ Ring worm } & $\begin{array}{l}\text { Mirchya ghass } \\
\text { (Cymbopogon martini) }\end{array}$ & $\begin{array}{l}\text { Leaf powder is mixed with mustard oil and rubbed } \\
\text { in infected part. }\end{array}$ & $5 g m(q d)(x 3 d)$ \\
\hline & $\begin{array}{l}\text { Awon (Rhododendron } \\
\text { anthopogon) }\end{array}$ & $\begin{array}{l}\text { Leaf powder is mixed with mustard oil and rubbed } \\
\text { in infected part. }\end{array}$ & $5 g m(q d)(x 7 d)$ \\
\hline & $\begin{array}{l}\text { Latjiri, Apamarg } \\
\text { (Achyranthes aspera) }\end{array}$ & Root paste is prepared for application. & $5 g m(q d)(x 7 d)$ \\
\hline \multirow[t]{2}{*}{ Carbuncles } & Lasun (Allium sativum) & $\begin{array}{l}5 \text { bulbs are ground and mixed with } 1 \mathrm{gm} \text { of salt } \\
\text { and made into a paste. }\end{array}$ & $5 g m(q d)(x 7 d)$ \\
\hline & Lesskuri (Galium aparine) & Leaf paste is prepared for application. & $5 g m(q d)(x 7 d)$ \\
\hline \multirow[t]{3}{*}{ Dermatitis } & Devdar (Cedrus deodara) & $\begin{array}{l}\text { Oil is mixed with Rubus paniculatus Sm. leaf } \\
\text { powder and used externally. }\end{array}$ & $5 \mathrm{ml}(\mathrm{qd})(\times 3 d)$ \\
\hline & $\begin{array}{l}\text { Mirchya ghass } \\
\text { (Cymbopogon martini) }\end{array}$ & $\begin{array}{l}\text { Leaf powder is mixed with mustard oil and rubbed } \\
\text { in affected part. }\end{array}$ & $5 g m(q d)(x 3 d)$ \\
\hline & Pangar (Aesculus indica) & Mature fruit coat is milled and made into a paste. & $5 g m(q d)(x 7 d)$ \\
\hline
\end{tabular}

\section{Discussion}

In the Bhotiya communities, traditional healers who prepare remedies also serve as diagnosticians, identifying causes of illness before prescribing treatment. The dose given to the patient depends on age, physical status and health conditions of the patient. The method of use of plants varies according to nature of disease. In the majority of the cases, a decoction of various parts of plants used is administered for treating a disease or diseases. Most of the decoctions are made just by crushing the plant parts but some are made by boiling plant parts in water, decanting of the liquid and drinking after cooling. Paste of some plants is plastered to set dislocated or fractured bones or muscular pain.

\section{Conclusions}

Traditional knowledge of plants in many communities is changing because of rapid socioeconomic and cultural changes that are taking place. This is particularly true in these tribal communities. Documentation of this knowledge is valuable both for the communities and their future generations and for scientific consideration of wider uses of the knowledge.

The indigenous knowledge and rights of the Bhotiya communities and local people regarding uses of plants needs to be secured. Appropriate mechanisms for effective benefits sharing of potential value of this knowledge need to be developed.

\section{Acknowledgements}

The authors are thankful to the Director, G.B. Pant Institute of Himalayan Environment and Development, KosiKatarmal Almora for providing necessary facilities. We are grateful to Prof. R.D. Gaur and Prof. M.C. Nautiyal for identification of the plant species and all local herbal healers for their kind cooperation and active participation in this study. The authors are also thankful to the National Medicinal Plants Board (NMPB), Government of India for financial support.

\section{Literature Cited}

Farooquee, N.A. 1994. Transhumance in the Central Himalaya: A study of its impact on environment. Ph.D. Thesis, HNB Garhwal University, Srinagar Garhwal, India.

Farooquee, N.A. \& K.G. Saxena.1996. Conservation and utilization of medicinal plants in high hills of Central Himalaya. Environmental Conservation 23:75-80. 
Gangwar, A.K. \& P.S. Ramakrishnan. 1990. Ethnobiological notes on some tribes of Arunachal Pradesh, northeastern India. Economic Botany 44:94-31.

Gaur, R.D. 1999. Flora of the district Garhwal North West Himalaya with ethnobotanical note. Transmedia, Srinagar, Garhwal, India.

Kala, C.P. 1998. Ethnobotanical survey and propagation of rare medicinal herbs for small farmers in the buffer zone of the Valley of Flowers National Park, Garhwal Himalaya. A Report. International Centre for Integrated Mountain Development, Kathmandu, Nepal.

Kala, C.P. 2002. Indigenous Knowledge of Bhotia tribal community on wool dying and its present status in the Garhwal Himalaya, India. Current Science 83:814-817.

Kala, C.P. 2005. Indigenous uses, population density and conservation of threatened medicinal plants in protected areas of the Indian Himalayas. Conservation Biology 19:368-378.
Maikhuri, R.K. \& A.K. Gangwar. 1993. Ethnobiological notes of the Khasi and Garo tribes of Meghalaya, north east India. Economic Botany 47:345-357.

Maikhuri, R.K., S. Nautiyal, K.S. Rao \& K.G. Saxena 1998. Role of medicinal plants in the traditional health care system: a case study from Nanda Devi Biosphere Reserve. Current Science 75:152-157.

Maikhuri, R.K., S. Nautiyal, K.S. Rao \& R.L. Semwal. 2000. Indigenous knowledge of medicinal plants and wild edibles among three tribal sub-communities of the Central Himalaya, India. Indigenous Knowledge Development Monitor 8:7-13.

Naithani, B.D. 1985. Flora of Chamoli. Pp 381-795 of Botanical Survey of India, Howrah. Volume 2. Department of Environment, New Delhi, India.

Nautiyal, S., K.S. Rao, R.K. Maikhuri, R.L. Semwal \& K.G. Saxena. 2000. Traditional knowledge related to medicinal and aromatic plants in tribal societies in a part of Himalaya. Journal of Medicinal and Aromatic Plant Sciences 23/4A \& 23/1A:528-441. 